\title{
Dél-Dunántúli szakrális emlékek Kiállítás a Rippl-Rónai Múzeumban, 2014. január 30 - április 10.
}

\author{
GÉGER MELINDA
}

Rippl-Rónai Megyei Hatókörű Városi Múzeum

H-7400 Kaposvár, Fő u. 101., e-mail: geger.melinda@gmail.com

\begin{abstract}
GÉGER, M.: South Transdanubian religious relics - Exhibition in the Rippl-Rónai Museum, Kaposvár 2014 from 30 January to 10 April.

Abstract: In 2014, special religious relic exhibition of art was displayed in the Rippl-Rónai Museum, Kaposvár. Some of the exhibited material came from those museums' collections found in South Transdanubia, while others were from private collections. The main aim of the exhibition was to find the local religious relics, again. Principally, this exhibition based on those relics which were moved by Sándor Klempa, the bishop of Veszprém from different Somogy County Baroque churches to the Diocese Collection, Veszprém in the 1950$60 \mathrm{~s}$. One of the most important part of the exhibition were those works painted by the most significant religious artists, István Dorffmaister and some church-related works from Rippl-Rónai Ödön's collection were also exhibited.
\end{abstract}

Keywords: Rippl-Rónai, Ödön Rippl-Rónai, Sándor Klempa, religious arts, István Dorffmaister, convent works, Mihály Zichy

A kaposvári Rippl-Rónai Múzeumban 2014-ben első ízben került sor kifejezetten szakrális müvészeti emlékeket felvonultató kiállításra. A kiállított anyag egy része a múzeum gyűjteményéből, másik része magángyűjtőktől és dél-dunántúli múzeumoktól kölcsönzött mútárgyakból állt. A művek az építészet kivételével az egyházművészet sokféle műfaját kívánták reprezentálni. A templomi oltárképek, magánájtatosságot szolgáló kisebb festmények mellett szentek, vértanuk szobrait, miseruhákat, könyveket, liturgikus tárgyakat, művészi igénnyel készített ötvösművészeti tárgyakat és üvegeket mutattunk be abból az időszakból, amikor az egyházművészet fogalma megszületett, tehát a 16 . századtól 20 . századi elejéig. ${ }^{1} A$ válogatás szempontja a dél-dunántúli keletkezés vagy megőrzés helye, tehát nem minden bemutatott alkotás született a régióban. A kiállítás spektrumát Somogyon túl a dél-dunántúli régióra terjesztettük ki, így a helyi anyag a zalai és tolna megyei múzeumi mütárgyakkal bővült.

$A z$ egyházművészet Somogy megyében kevéssé áll az érdeklődés homlokterében: Kaposvár későn, a rendszerváltás után a 90-es években vált püspöki székhellyé, korábban Somogy a Veszprémi Egyházmegyéhez tartozott. Az egyházművészet nagy történelmi korszakaihoz kötődő liturgikus tárgyak, amelyek hagyományosan az egyházközponti státusz jellegzetes kísérői, Kaposváron nem álltak rendelkezésre. Komolyabb müvek megszületését segítő papi megrendelések Somogyban nem voltak, és olyan reprezentatív

1 Elek Artúr: Egyházművészeti kiállítás, Nyugat, 1926. 20. sz. ISSN 2064-1966 (Print); ISSN 2631-0376 (Online) stílusoknak, mint a barokk, inkább provinciálisabb változatai vannak jelen. Az egyedüli számottevő egyházi témában dolgozó művész id. Dorffmaister István volt, akit a kiállítás megfelelőképpen reprezentált.

A kiállítás gondolata a szórványosan meglévő helyi értékek számbavételére született meg. Kiindulópontul egy történeti mozzanat szolgált: az 1950-60-as években Klempa Sándor püspök a veszprémi egyházmüvészeti gyűjteménybe mentett át számos, Somogy megyei kistemplomban található barokk kori, értékes müvészeti emléket. Ha erre nem került volna sor, elképzelhető, hogy sok mű semmisült vagy kallódott volna el abban a rendszerben, amely nem nagyon törődött a szakrális tárgyú műalkotásokkal. ${ }^{2} \mathrm{~A}$ veszprémi Boldog Gizella Főegyházmegyei Gyűjtemény somogyi anyagából $13 \mathrm{db}$ alkotást állítottunk ki, melyek egykor a következő települések templomait díszítették: Hahót, Osztopán, Büssü, Kaposvár, Mernye, Kisbárapáti és Somodorpuszta.

$A z$ eredeti, veszprémi anyagra koncentráló koncepció magától érthetődő módon bővült a Rippl-Rónai Múzeum gyűjteményéből származó müvekkel. A múzeum szakrális gyüjteménye kevés müvet tartalmaz, a meglévő darabok rossz állapotban vannak, és általában restaurálásra szorulnak. Több mü ezért nem volt kiállítható állapotban. A múzeum névadójának öccse, Rippl-Rónai Ödön szenvedélyes gyűjtő volt, és figyelme a korabeli modern művészeteken túl a régmúlt emlékeire is kiterjedt. Így kerültek gyüjteményébe barokk kori rajzok, szobrok festmények, liturgikus tárgyak és miseruhák is. (9. ábra) E mútárgyakat eddig csak részlegesen volt módunk bemutatni a nagyközönségnek. Első ízben látható néhány darab Rippl-Rónai Ödön grafikai gyűjteményéből, amely ismeretlen barokk kori itáliai és német-osztrák művészek rajzait tartalmazza.

A kiállítás egyik legfontosabb részét azok a müvek képezték, amelyeket Somogy legjelentősebb egyházi művésze, Dorffmaister István festett. Dorffmaister István ${ }^{3}$ (osztrák nevén Stephan Dorfmeister) születési helyéről és idejéről nem maradt fenn egyértelmü dokumentum. A nevét általában az előbbiként írta le, $\mathrm{s}$ mellette az akadémiai tagságát is feltűntette. A ku-

2 Köztudomású, hogy a rendszerváltás előtt számos egyházi érték került ki a templomokból a műkereskedelembe. Az állami gondoskodás hiánya következtében a közgyüjteményekben is mostohább sorsa volt ezeknek az anyagoknak: a nevesebb mesterek vagy értékesebb műtárgyak kivételével sok olyan mü található a raktárakban, amelyeknek restaurálása pénz hiányában elmaradt.

3 Horváth János: Somogy megye helyismereti könyve. Kaposvár, 2000. 115. o. 
tatások azt valószínüsítik, hogy 1729-ben Bécsben született, 1751-ben iratkozott be a bécsi akadémiára és 1758-ban végzett. 1762-ben Sopronban telepedett le, ahol nem lett magyar polgár, de haláláig ott lakott. Franz Annával kötött első házasságából kilenc gyermeke született. ${ }^{4}$ A 18. század egyik legtermékenyebb és leginkább kedvelt festője volt, akit a maga korában versekkel is ünnepelték. Első munkáin még érezhető bizonytalanságok mutatkoztak a barokk freskókra jellemző, merész alulnézetben ábrázolt emberábrázolásokban. Stílusát tekintve a rokokóval átitatott bécsi akadémizmusból kiindulva Maulbertsch expresszív töltésű festészete jelöli ki fejlődésének irányát, majd 1780 körül klasszicista irányú stílusváltozás következett be nála. Dorffmaister a bécsi késő barokk templomi müvészet művelőjeként az egész Dunántúl területén dolgozott, így munkássága fontos szerepet töltött be a müvészeti köznyelv magyarországi elterjesztésében. Somogyban több helyen maradtak fenn alkotásai, köztük a kiállításon is látható gálosfai Szt. Lukács oltárkép. A szent főalakjában saját magát örökítette meg. ${ }^{5}$ (4. ábra) $A$ másik jelentős mü, a zicsi Körmeneti baldachin (1790) egy körmeneti zászló részeként volt megtekinthető a kiállításon. (5. ábra) A hideg színekre komponált mü a késő rokokó és a nyugodt, centrális kompozíciójú kora klasszicista stílus sajátos ötvözeteként egyike a müvész kiemelkedő liturgikus tárgyainak. Dorffmaister a templomi munkák mellett föúri arcképek megfestésére is sok megbízást kapott. A kaposvári Szt. Kereszt Római Katolikus Plébánia két oltárképének Dorffmaisterhez kapcsolódó attribuciója bizonytalan, de mindkét oltárképen hangsúlyos a portrémegjelenítés igénye és a klasszicizáló komponálás szándéka.

A múvész megbízásait jobbára azoktól kapta, akiknek nem volt elég pénze a divatos bécsi mesterek megfizetésére. Nehéz anyagi viszonyok között élt, állandó adósságokat vállalt. 1797. május 29-én halt meg Sopronban 68 éves korában. Óriási munkássága ellenére halálával jórészt csak adósságokat hagyott örökül családjára. Életművében a világi témájú, kastélydekorációnak készült falképek száma csekély. Somogy megyei templomokban 12 helyen találhatók Dorffmaister-művek, ezért a kaposvári kiállítás egyik szobáját a mester somogyi templomokban és a zalaegerszegi múzeumban található müveinek szenteltük.

A tárlat fő hangsúlyait a barokk kor alkotásai, a jórészt ismeretlen mesterek keze nyomán készült mütárgyak képezik. Közülük több különleges darab származott kaposvári magángyűjteményekből. A sziléziai festő: Halott Krisztus a Fájdalmas Szüz ölében (1700 k.) címü kép a barokk stílus jellegzetes, mozgalmasságra törekvő látásmódját közvetíti. A túlfütött érzelmi hatás érdekében felfokozva jeleníti meg a szentek vallásos révületét, pátosszal és színpadiasan ábrázolja

4 Közülük három fia folytatta apja festői mesterségét: József, István és Vince. József az apja mellett architektúra festőként dolgozott. Az ifjabb István, Dorffmaister István József Pál (Sopron, 1770 - Sopron, 1807) szintén apja mellett dolgozott, „Stephan Dorffmeister" aláírással szignálta műveit.

5 Kostyál László művészettörténész, Dorffmaister-kutató közlése szereplöit. Ezért különösen fontos az arckifejezések, érzelmek sokféle skálája. A korszak késői, rokokóba hajló változatai jelennek meg az ismeretlen francia művész: Izsák feláldozása (18. sz. második fele), illetve a Johannes Kracker mühelyéből származó Mária mennybevitele c. alkotásokon. Az Izsák feláldozása eredetileg a Zichy Mihály gyűjteményben egyik tárgydarabja volt. A képet Zichy franciaországi tartózkodása idején, 1870-75 között vásárolta és hozta haza, vélhetően egy francia művész keze munkájaként. (8. ábra) A könnyedebb, finoman karcsú, törékeny alakokat tekintve e művek formaképzésében már a rokokó báj és könnyedség nyilatkozik meg. A hideg-meleg színek, a hangsúlyos fény- és térhatások mellett a felfokozott érzelmeket játékosabban, könnyedebb előadásmódban közvetítik. Az Izsák feláldozása jelenetben a keresztény, ószövetségi történetet a művész antik római figurákkal és motívumokkal egészítette ki. Hasonló jelenséget figyelhetünk meg a szekszárdi múzeum Jákob létrája (18. század vége) c. képén, ahol a bibliai jelenetet a rokokó fête galante formájában örökítette meg a naiv müvész. (11. ábra)

Dorffmaister István mellett a kiállítás másik, név szerint is ismert és egyben jelentős alkotója a somogyi származású festő, Zichy Mihály. A művész zalai Emlékmúzeumából néhány különleges emléktárgyat mutatunk be. Első ízben volt a közönség előtt látható Kaposváron a Krisztus a keresztfán (1846) c. festménye, amely jelenleg a zalai templom oltárképeként funkcionál. ${ }^{6} \mathrm{~A}$ mü - hasonlóan több más fiatalkori Zichy alkotáshoz - egy rejtett önarckép, a Megváltó arcvonásaiba a művész saját portréját festette meg. Keletkezésének idején a fiatal művész már a művészi pályára készült, és a képet emiatt, egyfajta engesztelésül festette édesanyjának. $\mathrm{E}$ művészi gesztusban már azzal is szembesülünk, hogy a 19. századra miként töltődik fel az eredeti szakrális mondanivaló világias tartalmakkal. A Zichy család tulajdonában volt az a különleges, faragott neogótikus házioltár (19. sz.) is, amely szintén Franciaországból származik. Valószínünek tartjuk, hogy a Párizsi Magyar Egylet mühelyének iparostanoncai készítették. Felvethető, hogy az oltárt maga Zichy Mihály tervezte, mint arra egy másik esetben, egy Zichy család címerével ellátott és hasonló jellegű könyvszekrény is utal. ${ }^{7}$ A jellegzetes neogótikus architektúrával ellátott oltár nyitott szárnyainak belö oldalába süllyesztve, ezüstözött ovális cinklemezek örökítik meg a Golgota történetét. (2. ábra) Szintén a zalai Zichy gyüjtemény egyik nevezetes darabja az ismeretlen művésztől származó elefántcsont Feszület (19. sz.), amely a kidolgozás finomságával az egyik legszebb és egyben legértékesebb darabját képezte a kiállított együttesnek. (1. ábra)

A kiállítás szobrászati anyagát jórészt a veszprémi Boldog Gizella Főegyházmegyei Gyűjtemény eredetileg somogyi kistemplomokban álló plasztikái reprezentálták. A müvek alkotói ismeretlen, provinciális mesterek. A barokk plasztika alakjai szinte táncos

6 Elsőként közölve Zichy Mihály. A rajzoló fájdalma. 2007. MNG katalógus, 11. o.

7 A szekrény magánygyűjteményben található. 
mozgásúak, a ruhák redői bonyolult ritmusúak, ami a kismesterek kezén darabosabb, nehézkesebb formaképzéssel jeleneik meg. (Szent István és Szent László alakjai, 18. sz.) (3. ábra) A kiállított anyagból említést érdemel az eredetileg büssüi származású Kálvária szoborcsoport is (18. sz.). A gótikus szobrászat jellegzetes Szép Madonnáinak késői leszármazottjai a barokk provinciális szobrászatban, majd népi változatban megjelenő számos Mária ábrázolás. E csoporthoz tartozik a kaposvári múzeum tulajdonában lévő, a több példányban és különböző méretben megjelenő Andocsi Mária elnevezésű kegyszobor. A típus Andocs település híres barokk kori Madonnájára utal, melynek feldolgozásai megjelentek a szakrális népi szobrászatban. A plaszikák közös jellemzője, hogy a a gyermek Jézust kezében tartó Madonna koronát visel. (7. ábra)

A tárlókban a fontos liturgikus kellékek, miseruhák, gyertyatartók, körmeneti zászlók, misecsengők, keresztelőkupák és áldozókelyhek jelentek meg. E tárgyak közül az egyik legszebb együttes a szintén Büssüböl származó keresztszemes miseruha, stóla, bursa és manipulus, illetve technikája révén ide kapcsolódott az osztopáni Körmeneti zászló is, amelyben keresztszemes burdür veszi körül megfeszített Krisztus képét. (1. ábra) $\mathrm{E}$ mútárgyanyagot különleges könyvritkaságok egészítették ki: részben a Rippl-Rónai Múzeum tulajdonából, részben kaposvári magánygyüjteményekből. A 16-17. századi, metszetekkel is díszített, külföldön nyomtatott kiadványok közül a frankfurti Ó- és Új Testamentum (1571) Frankfurt vagy a Kölnből származó korai Luther Biblia (1567) a legnevezetesebb.

A 18-19. századra a barokk művészet leegyszerüsödve eljutott a polgárság és a magyar parasztság otthonaiba is. A népies vagy provinciális barokk szép házioltárok, kisebb fafaragványok, zárdamunkák és kegytárgyak formájában jelent meg. A zárdamunka egy sajátos, több művészeti műfajt ötvözö, kis méretü, szakrális tartalommal bíró tárgy. Eredendően apácák készítették, de a 19. századi kolostorokban nevelkedő nemesi családok leányai is szívesen töltötték idejüket készítésével. A technikát tekintve általában a hímzések domináltak, amit a művészi látásmóddal rendelkező, névtelen készítő további változatos anyagok (csont, fa, gyöngy) beiktatásával, plasztikus betétekkel és esetenként festett részletekkel is kiegészített. A kaposvári kiállításon több érdekes zárdamunka volt megtekinthető, közülük említésre méltó a miniatür kidolgozású Zárdamunka csont feszülettel (19. sz.). Az időben elöre haladva változik a szakrális tárgyakban felhasznált anyagok minősége és a kidolgozás technológiája. A 19. század végére egyre olcsóbb anyagokból készülnek a tárgyak, ekkor jelennek meg a több példányban való megjelenítést lehetővé tevő technikák. Az elmúlt évszázadokban a nagy mesterek alkotásai elsősorban rézmetszetekben sokszorosítva váltak ismertekké: Raffaello, Guercino, Tiziano és más művészek képein szereplő figurák tűnnek fel a Rippl-Rónai Ödön gyűjtemény grafikáin, melyek a kor jó minőségű rézmetsző mühelyeiben készültek. Az ikonok paraszti világban is megjelenő legegyszerübb példái hengerelt üvegre készített, naiv

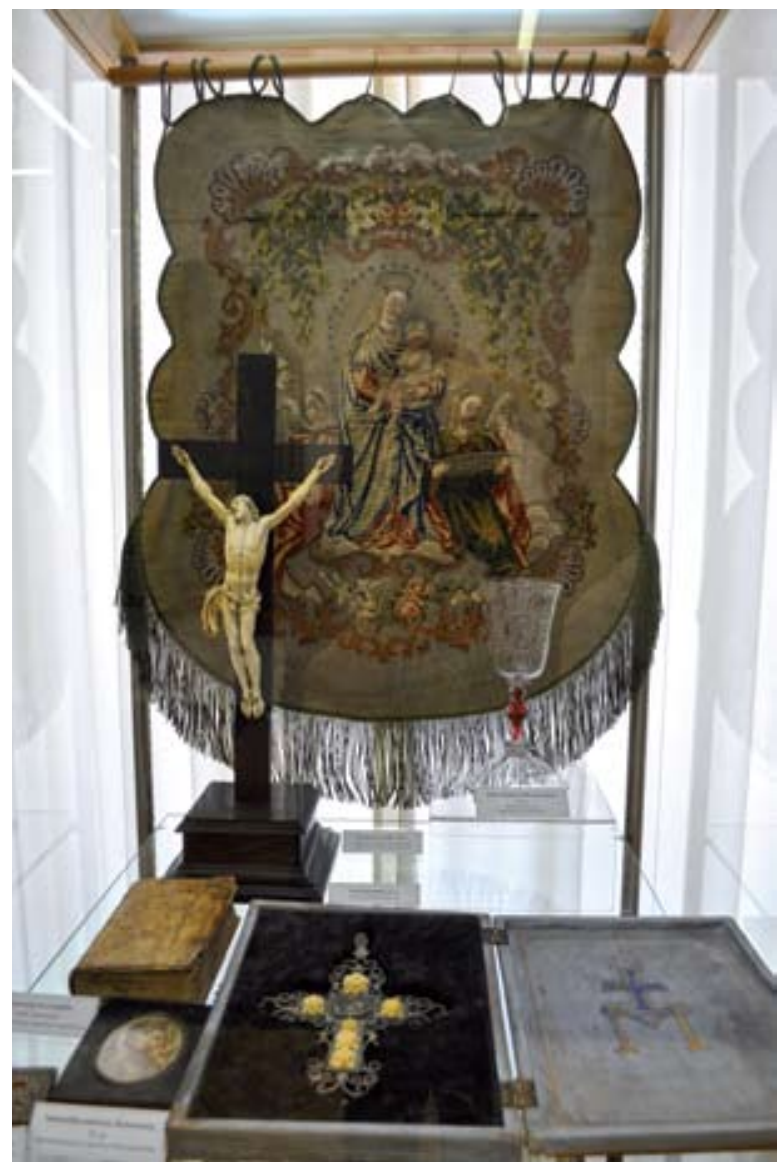

1. ábra: Részlet a kiállításból

üvegfestmények voltak. Az ikonképek népies átdolgozásaiban a trébelt fémborítást fólia, míg a növényi ornamentikákat a kivágott és sodrott fóliából alakították ki, melyek a domború díszítményeket helyettesítették. (6. ábra) A plasztikákat tekintve a porcelán és gipszöntvények megjelenítése hozott egyfajta forradalmat az olcsó kegytárgyak terén. Ide kapcsolódott kiállításunkon egy, a korai Zsolnay mühelyből származó, domború üveggel ellátott, ovális keretezésű porcelán Madonna is (19. sz. közepe).

Kiállításunkat a veszprémi Boldog Gizella Főegyházmegyei Gyűjtemény, a szekszárdi Wosinsky Mór Megyei Múzeum, a zalaegerszegi Göcseji Múzeum, a zalai Zichy Mihály Emlékmúzeum, a kaposvári Szent Kereszt Római Katolikus Plébánia, a zalai, gálosfai és más somogyi templomok és magánygyűjtemények segítségével rendeztük meg. Arra törekedtünk, hogy a rendezvénnyel a múzeumok raktáraiban, eldugott kis falvakban megőrzött rejtett egyházi kincsekre, mint megóvandó örökségünkre hívjuk fel a figyelmet. 


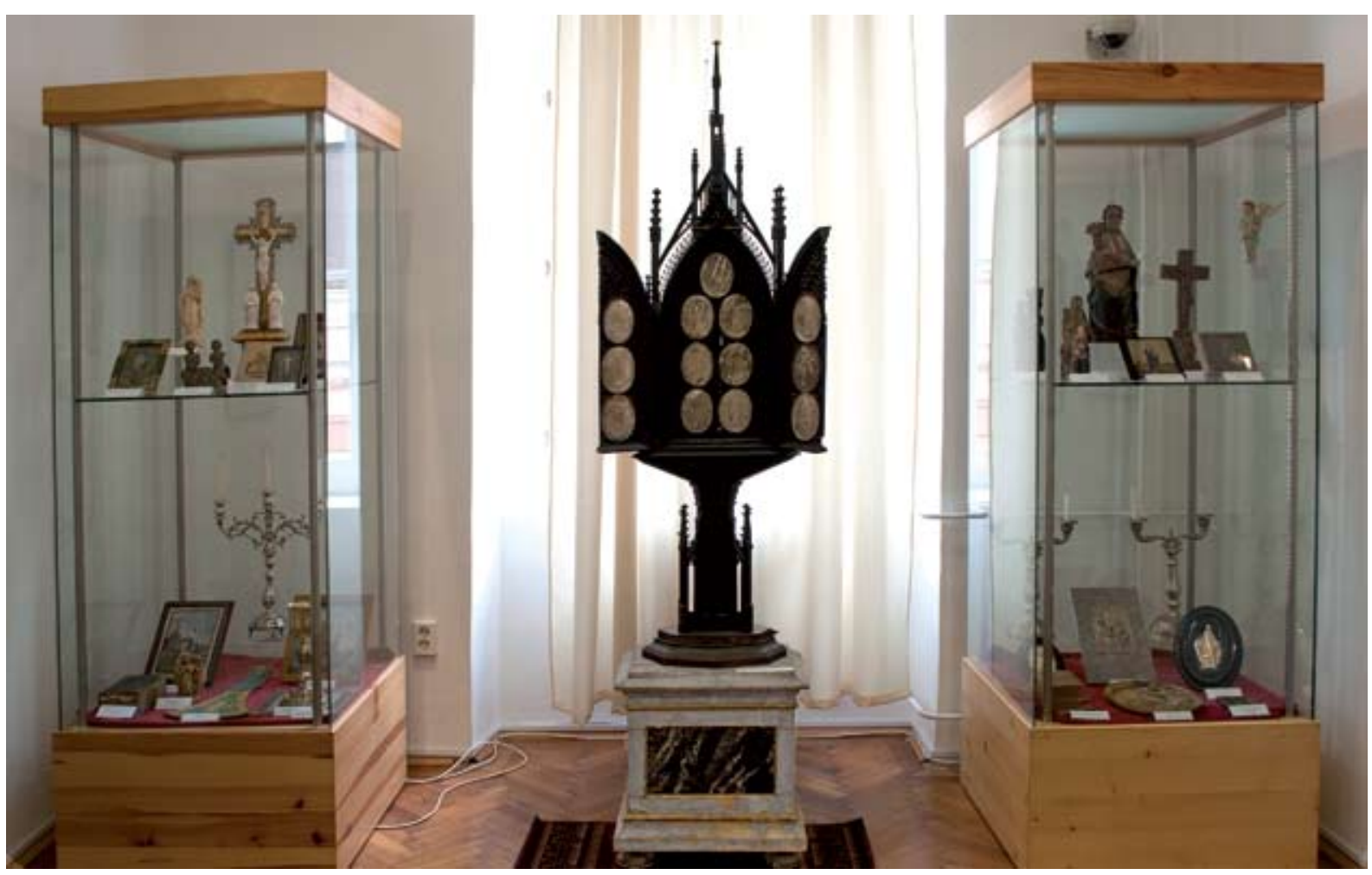

2. ábra: Részlet a kiállításból

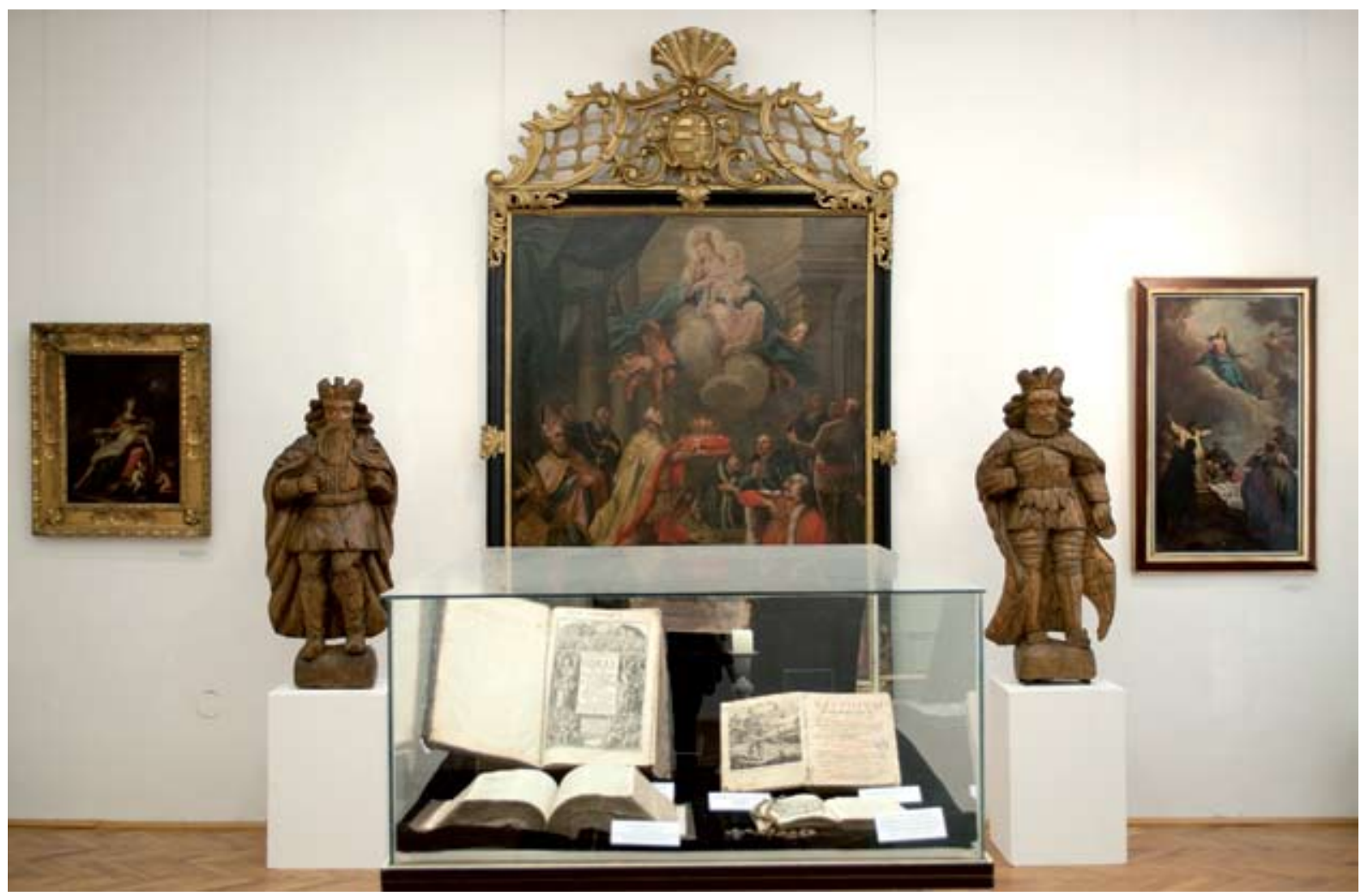

3. ábra: Részlet a kiállitásból 


\section{SZOBROK:}

Madonna a gyermekkel (kegyszobor), 19. század vége, faragott, festett fa, $29,5 \times 8 \mathrm{~cm}$, Itsz.: $89.594 / 1$, Boldog Gizella Főegyházmegyei Gyűjtemény

Ülő Madonna a gyermekkel, 20. sz. eleje, faragott, festett fa, 23,5×8,5 cm, Itsz.: 89.595. Származás: Hahót, Boldog Gizella Főegyházmegyei Gyűjtemény,

Feltámadt Krisztus, 19. század vége, faragott, festett fa, $55 \mathrm{~cm}$, Itsz.: 89.605. Boldog Gizella Főegyházmegyei Gyűjtemény

Szent István, Magyar mester munkája, 18. század, faragott, festett fa, $112 \mathrm{~cm}$, Itsz.: 89.221. Boldog Gizella Főegyházmegyei Gyűjtemény

Szent László, Magyar mester munkája, 18. század, népies, faragott, festett fa, $110 \mathrm{~cm}$, Itsz.: 89.222 . Boldog Gizella Főegyházmegyei Gyűjtemény

Szentháromság, Magyar mester munkája, 18. század második fele, festett fa, $39 \mathrm{~cm}$, Itsz:: 89.670. Boldog Gizella Főegyházmegyei Gyűjtemény

Kálvária szoborcsoport (pálos faragás) 18. század, hársfa, faragott, festett, $79 \mathrm{~cm}$, Mária :33cm; János: $33 \mathrm{~cm}$; Magdolna: $23 \mathrm{~cm}$, Itsz.: 89.117. Származás: Büsü, majd Kaposvári rk. templom, Boldog Gizella Főegyházmegyei Gyűjtemény, Veszprém

Szent Ferenc /Térdelő ferences szerzetes, 18. század eleje, fa, faragott, festett, $100 \mathrm{~cm}$, Itsz.: 89.789. Származás: Mernye, Boldog Gizella Főegyházmegyei Gyűjtemény, Veszprém

SzentAntal, 19. század első fele, népi, szakrális,tölgyfa, faragott, festett, $86 \mathrm{~cm}$, Itsz.: 89.599. Származás: Somogy, Kisbárapáti, Boldog Gizella Főegyházmegyei Gyűjtemény, Veszprém

Szent Erzsébet, 18. század közepe, olasz, hársfa, faragott, festett, Itsz.: 89.18. Származás: Somodorpuszta, Boldog Gizella Főegyházmegyei Gyüjtemény, Veszprém

Fájdalmas anya szobor, 18. század vége, fa, faragott, festett, 82 cm, Itsz.: 89.19. Származás: Mernye, Boldog Gizella Főegyházmegyei Gyűjtemény, Veszprém

Ismeretlen 18. századi szobrász: Szent Vendel, fa, aranyozott, M:108 cm, sz: $53 \mathrm{~cm}$, In. Wosinsky Mór Megyei Múzeum, Szekszárd

Ismeretlen 18. századi szobrász: Szt. Ferenc, fa, Itsz:: 74.1.61. Rippl-Rónai Múzeum, Rippl-Rónai Ödön gyűjteménye

Faragott noegótikus szárnyasoltár, 19. sz. $161 \times 46 \times 25,5$, fa, trébelt, ezüstözött cinklemez, oltár posztamens: $52 \times 51 \times 34$, fa, Zichy Mihály Emlékmúzeum, Zala
Ismeretlen 18. századi szobrász: Feltámadó Krisztus, festett, aranyozott fa, m: $65 \mathrm{~cm}$, sz: $18 \mathrm{~cm}$, mé: $14 \mathrm{~cm}$, Rippl-Rónai Múzeum, Rippl-Rónai Ödön gyüjteménye

Angyal aranyozott szárnyakkal, 19. sz. fa, Itsz.: 89. 127. Rippl-Rónai Múzeum

\section{FESTMÉNYEK, GRAFIKÁK:}

Ismeretlen 18. századi festő: Férfi és női szent, olaj, vászon, $30 \times 36 \mathrm{~cm}$, Itsz.: 65.8. Rippl-Rónai Múzeum

Ismeretlen 19. sz. festő: Krisztus sírba tétele, töredék, olaj, vászon, $21,5 \times 28 \mathrm{~cm}$, Itsz.: 55.483 . RipplRónai Múzeum, Rippl-Rónai Ödön gyüjteménye

Zichy Mihály: Krisztus a keresztfán, 1846. olaj, vászon, $160 \times 110 \mathrm{~cm}$, Zala, Római Katolikus Templom

Dorffmaister István: Szt Lukács oltárkép, 18. sz. olaj, vászon, $210 \times 120 \mathrm{~cm}$, Gálosfa, Római Katolikus Templom

Dorffmaister István: Körmeneti baldachin, 1790. olaj, vászon, $130 \times 190 \mathrm{~cm}$, Zics

Dorffmaister István(?): Oltárkép, ismeretlen pápa képével, olaj, vászon, $210 \times 110 \mathrm{~cm}$ Kaposvár, Szent Kereszt Római Katolikus Plébánia

Dorffmaister István (?): Nagy Szent Család ábrázolása (Jézus földi szüleivel és nagyszüleivel), 18. sz. vége, olaj, vászon, $210 \times 110 \mathrm{~cm}$, Kaposvár, Szent Kereszt Római Katolikus Plébánia

Ismeretlen festő: Szt. Rókus látomása, 19. sz. eleje, olaj, vászon, 93×69 cm, Itsz. K.76.1.20. Göcseji Múzeum , Zalaegerszeg

Ismeretlen festő: Betlehemi jelenet, 18. sz. közepe(?), olaj, vászon, $70 \times 83 \mathrm{~cm}$, Itsz. K.76.1.26. Göcseji Múzeum , Zalaegerszeg

Ismeretlen festő: Koronás Madonna, 19. sz. első fele, olaj, vászon, $92,5 \times 79,5 \mathrm{~cm}$, Itsz. K.76.1.37. Göcseji Múzeum , Zalaegerszeg

Ismeretlen festő: Ismeretlen festő: Ószövetségi jelenet, 18. sz, fatábla, vászon, $135,5 \times 100 \mathrm{~cm}$, Itsz. K.76.3.38. Göcseji Múzeum , Zalaegerszeg

Ismeretlen festő (Dorffmaister István?): Szt. Pál megtérése, 18 . sz, olaj, rézlemez, $109 \times 87,5 \mathrm{~cm}$, Itsz. K.76.1.39. Göcseji Múzeum , Zalaegerszeg

Ismeretlen festő: Szt. István felajánlja a koronát, 18. sz. vége, olaj, vászon, $177 \times 136,5 \mathrm{~cm}$, Itsz K.54.1.10. Göcseji Múzeum , Zalaegerszeg

Ismeretlen festő a 19. század elejéröl: Szent Mihály Arkangyal, olaj, vászon, $63 \times 50,5 \mathrm{~cm}$, Itsz.: 56.7 . Wosinsky Mór Megyei Múzeum, Szekszárd 
18. századi szentképfestő: Férfiszent a gyermek Jézussal, olaj, vászon, $78 \times 65 \mathrm{~cm}$, Itsz:: 56.110 . Wosinsky Mór Megyei Múzeum, Szekszárd

Lotz Károly (1833-1904): Kánai menyegző, papír, akvarell, 23×45 cm, Itsz.: 65.55. Wosinsky Mór Megyei Múzeum, Szekszárd

Ismeretlen festő: Jákob létrája, 18. század vége, olaj, vászon, $136 \times 190 \mathrm{~cm}$, Itsz.: 84.17. Wosinsky Mór Megyei Múzeum, Szekszárd

Mária a gyermek Jézussal, házioltár, 19. sz. vegyes technika, fa, fém, olaj, $52,5 \times 46,5 \mathrm{~cm}$, Itsz.: 84.5.1. Rippl-Rónai Múzeum

Hegedüs László: Szent Család, olaj, vászon, 36×44 cm, Itsz.: 55.15. Rippl-Rónai Múzeum, Rippl-Rónai Ödön gyüjteménye

Ismeretlen müvész: Stáció kép, 18. sz. olaj, vászon, $66 \times 100 \mathrm{~cm}$, Itsz.: 55.483. Rippl-Rónai Múzeum, Rippl-Rónai Ödön gyűjteménye

Pravoszláv ikon, aranyozott fa, olaj, $44 \times 56,5 \mathrm{~cm}$, Itsz.: 64.267. Rippl-Rónai Múzeum

Ismeretlen 19. sz-i festő: Szent Család, olaj, vászon, $26 \times 21 \mathrm{~cm}$, Itsz.: 55.514. Rippl-Rónai Múzeum, Rippl-Rónai Ödön gyüjteménye

Goszthony Mária: Krisztus sírbatétele, kerámia, 49×39 cm, Itsz.: 2008.1. Rippl-Rónai Múzeum

Olasz festő: Apostol (Dús szemöldökű férfi mellképe) 19 . sz. olaj, vászon, $39,5 \times 33 \mathrm{~cm}$, Itsz.: 65.13 . Rippl-Rónai Múzeum

Ismeretlen 19. sz-i festő: Madonna a gyermekkel, olaj, vászon, $35 \times 29 \mathrm{~cm}$, Itsz:: 55.513 . Rippl-Rónai Múzeum, Rippl-Rónai Ödön gyűjteménye

Ismeretlen 18. századi művész: Szentháromság kompozíció Madonnával és egy szenttel, papír, kréta, 40,5×29,5 cm, Itsz.: 2014.2.2. Rippl-Rónai Múzeum, Rippl-Rónai Ödön gyűjteménye

Ismeretlen művész: Krisztus meghallgatása Pilátus előtt, 18. sz. papír, színezett rézmetszet, $43 \times 54,8$ cm, Itsz.: 2014.2.3. Rippl-Rónai Múzeum, RipplRónai Ödön gyűjteménye

Ismeretlen művész: Mária oltár magyar szentekkel, színezett rézmetszet, $50 \times 29,6$ cm, Itsz.: 2014. 2.4 . Rippl-Rónai Múzeum, Rippl-Rónai Ödön gyűjteménye

Szent Márton és a koldus, 18. század, papír diópác, akvarell, 33,4×24,9 cm, Itsz.: 2014.2.5. Rippl-Rónai Múzeum, Rippl-Rónai Ödön gyűjteménye

Ismeretlen 18. sz-i művész: Kronosz, az idő allegóriája, papír, lavírozott tus, 16,5×16,5cm, Rippl-Rónai Múzeum, Rippl-Rónai Ödön gyűjteménye

Ismeretlen múvész: Szt János evangelista (?) (Raffaello után) 1860. papír, rézmetszet, $22 \times 17 \mathrm{~cm}$, RipplRónai Múzeum, Rippl-Rónai Ödön gyűjteménye
Ismeretlen 19. sz-i művész: Szt. Pál apostol (Guercino után) papír, rézmetszet, $25 \times 20,5 \mathrm{~cm}$ Rippl-Rónai Múzeum, Rippl-Rónai Ödön gyűjteménye

Ismeretlen 19. sz-i művész: Imádkozó Szűz Mária, papír, rézmetszet, Rippl-Rónai Múzeum, Rippl-Rónai Ödön gyüjteménye

Sziléziai festő: Halott Krisztus a Fájdalmas Szűz ölében, 1700 k. olaj, fémlemez $58 \times 45 \mathrm{~cm}$, magántulajdon

Johann Kracker mühelye: Mária mennybevitele, 18. Sz. vége, olaj, vászon, $100 \times 57 \mathrm{~cm}$, magántulajdon

Ismeretlen művész: Izsák feláldozása, 18. sz. vége, olaj, vászon, magántulajdon

Ismeretlen művész: A betlehemi gyermekgyilkosság, 19. sz., papír, kréta, $52 \times 42,5 \mathrm{~cm}$, jn., magántulajdon

Házioltár, 20. sz. eleje, porcelán, textil, metállal aranyozott fa keret, üveg, $70 \times 53 \mathrm{~cm}$, magántulajdon

Kereszt két szenttel, 19. sz-i népi üvegfestmény, üveg, olaj, $25 \times 21 \mathrm{~cm}$, magántulajdon

\section{TÁRLÓKBAN:}

Egykarú gyertyatartó, ón, Itsz.: 80.9.1. Rippl-Rónai Múzeum

Egykarú gyertyatartó, ón, 80.9.2. Rippl-Rónai Múzeum

Miseruha, 19. század közepe, kongréalap, keresztöltéses hímzéssel, 96×78 cm, Itsz.: 89.273/1. Származás: Büsü, Boldog Gizella Főegyházmegyei Gyűjtemény, Veszprém

Stóla, 19. század vége, magyar, kongré, keresztöltéses hímzés. $210 \times 26$ cm, Itsz.: 89.273/3, Származás: Büsü, Boldog Gizella Főegyházmegyei Gyűjtemény, Veszprém

Bursa, 19. század vége, magyar, olajzöld kongré, keresztszemes hímzés, $20 \mathrm{~cm}$, Itsz.: 89.273. Származás: Büsü, Boldog Gizella Főegyházmegyei Gyűjtemény, Veszprém

Manipulus, 19. század vége, magyar, kongré, keresztszemes hímzés, $28 \mathrm{~cm}$, Itsz.: 89.273. Származás: Büsü, Boldog Gizella Főegyházmegyei Gyűjtemény, Veszprém

Miseruha, 17. sz. Fémszálas hímzésü, barokk miseruha. Rippl-Rónai Múzeum, Rippl-Rónai Ödön gyűjteménye

Miseruha (loannes Kis), 18. sz. vége, származás: Sándorháza, dalmatika kék alapon hímzett, m: 90 $\mathrm{cm}$, sz: $106 \mathrm{~cm}$. Rippl-Rónai Múzeum, Rippl-Rónai Ödön gyűjteménye 
KIÁLLÍTÁS A RIPPL-RÓNAI MÚZEUMBAN, 2014. JANUÁR 30 - ÁPRILIS 10.

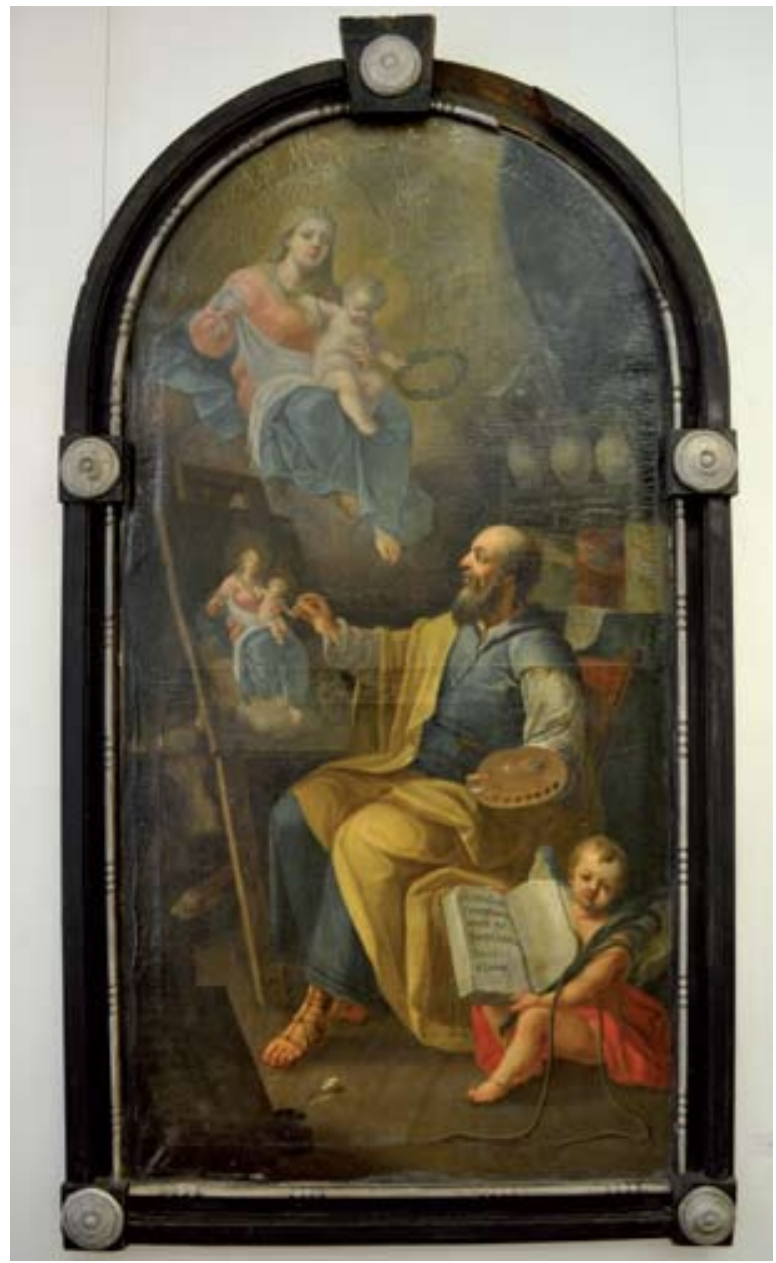

4. ábra: Dorffmaister István: Szt Lukács oltárkép, 18. sz. Gálosfa, Római Katolikus Templom

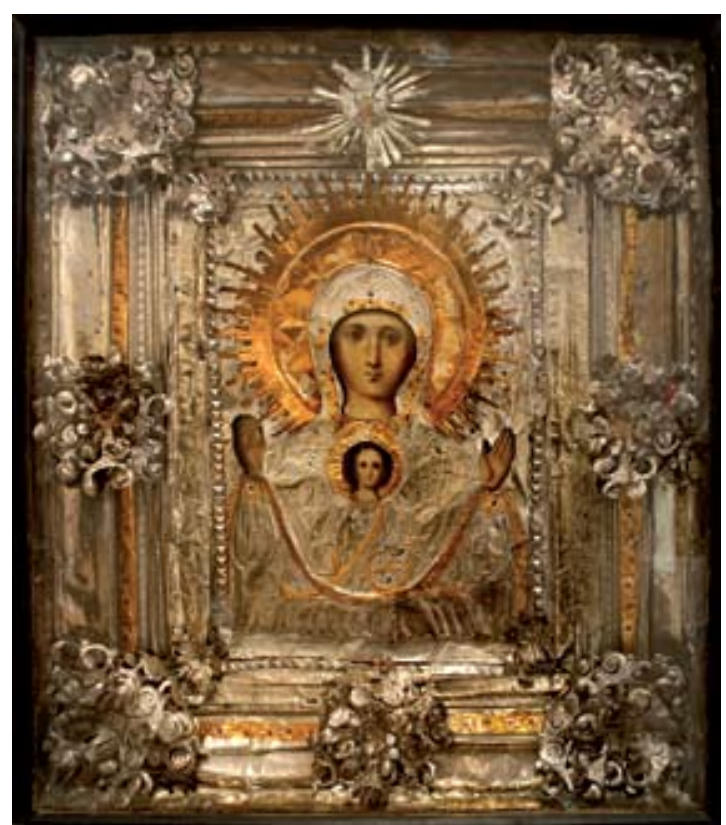

6. ábra: Mária a gyermek Jézussal, házioltár, 19. sz. Rippl-Rónai Múzeum

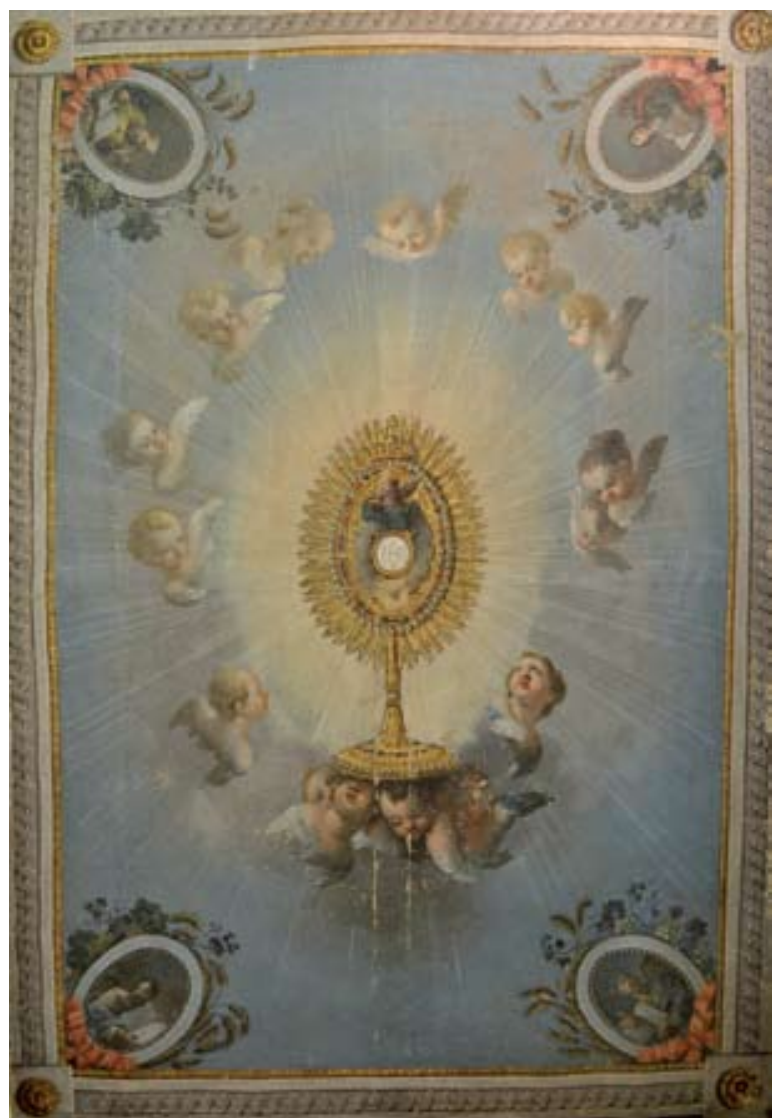

5. ábra: Dorffmaister István: Körmeneti baldachin, 1790. Zics

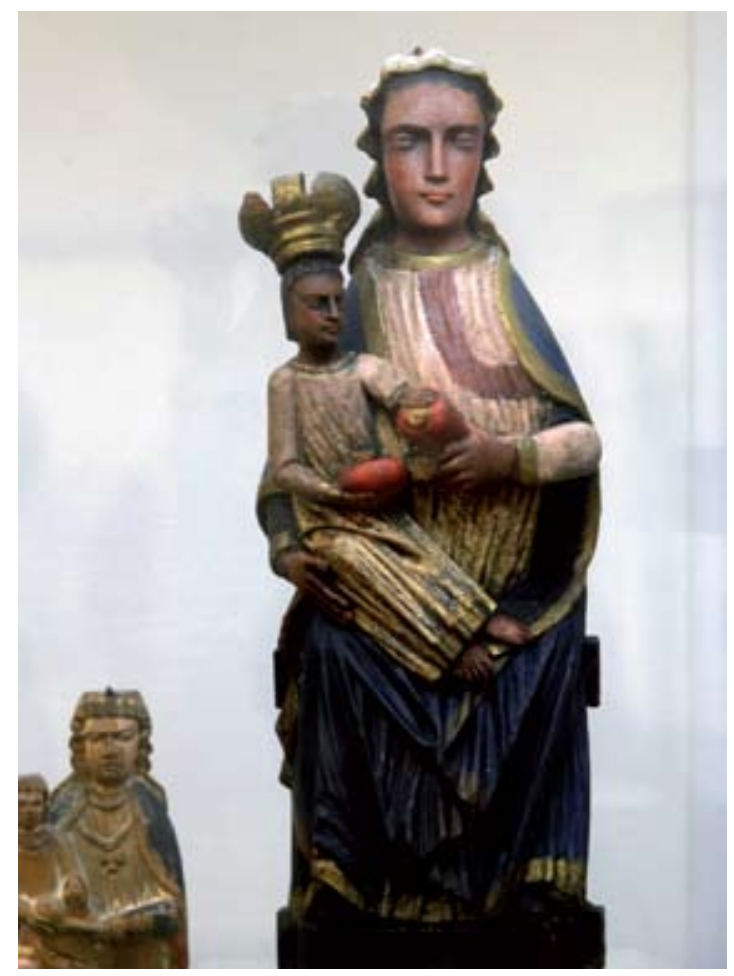

7. ábra: Andocsi Mária kegyszobor, 19. sz. Rippl-Rónai Múzeum 


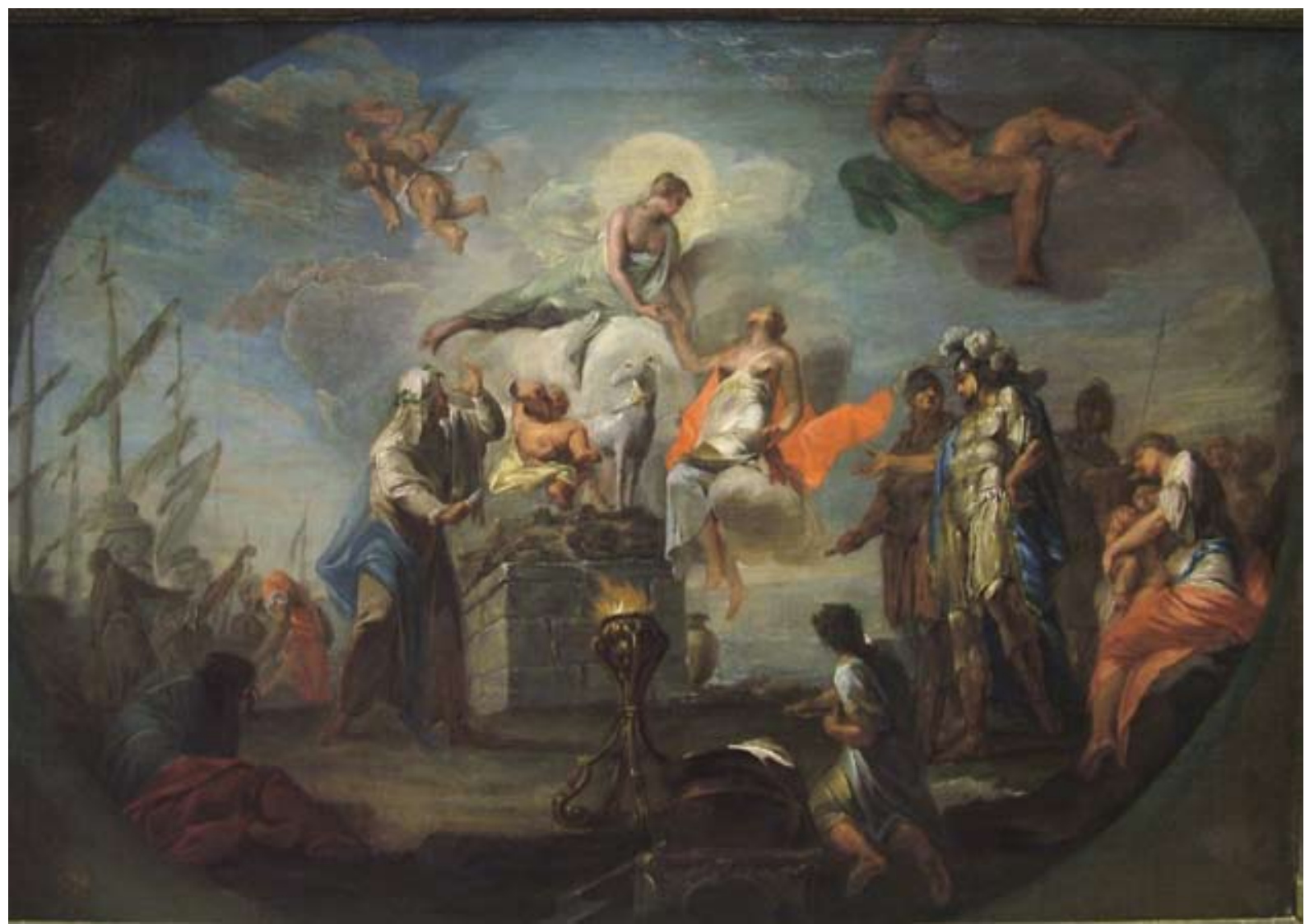

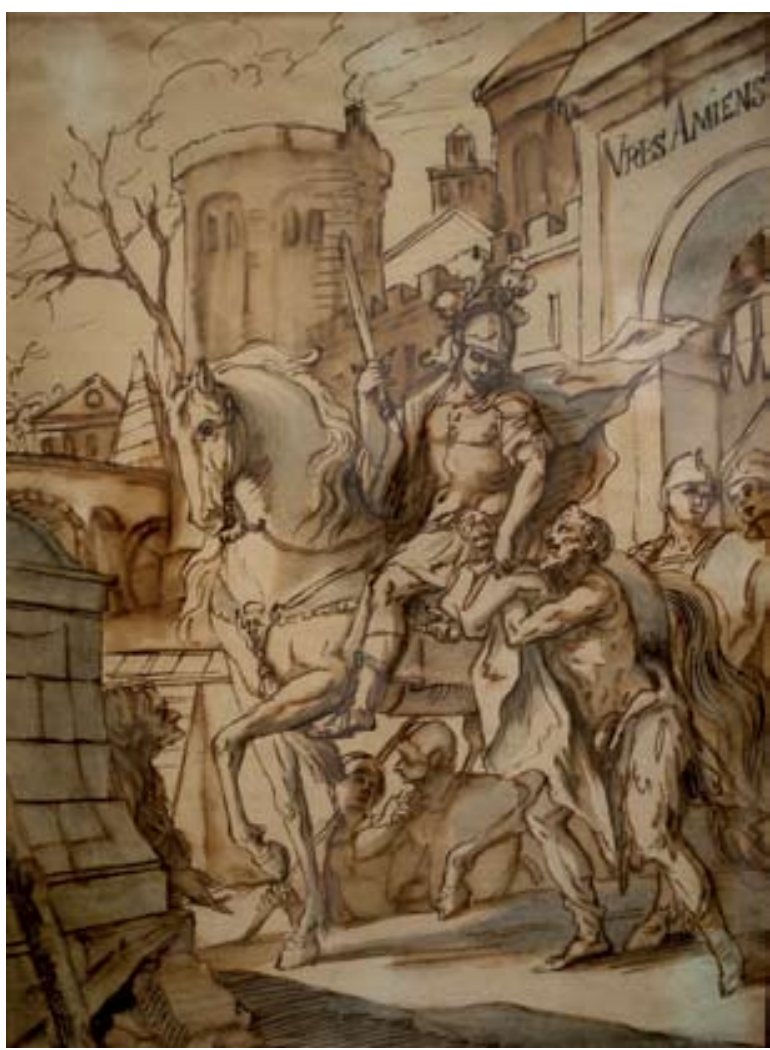

9. ábra: Ismeretlen müvész: Szent Márton és a koldus, 18. század, Rippl-Rónai Múzeum
8. ábra: Ismeretlen francia müvész: Izsák feláldozása, 18. sz. vége, magántulajdon

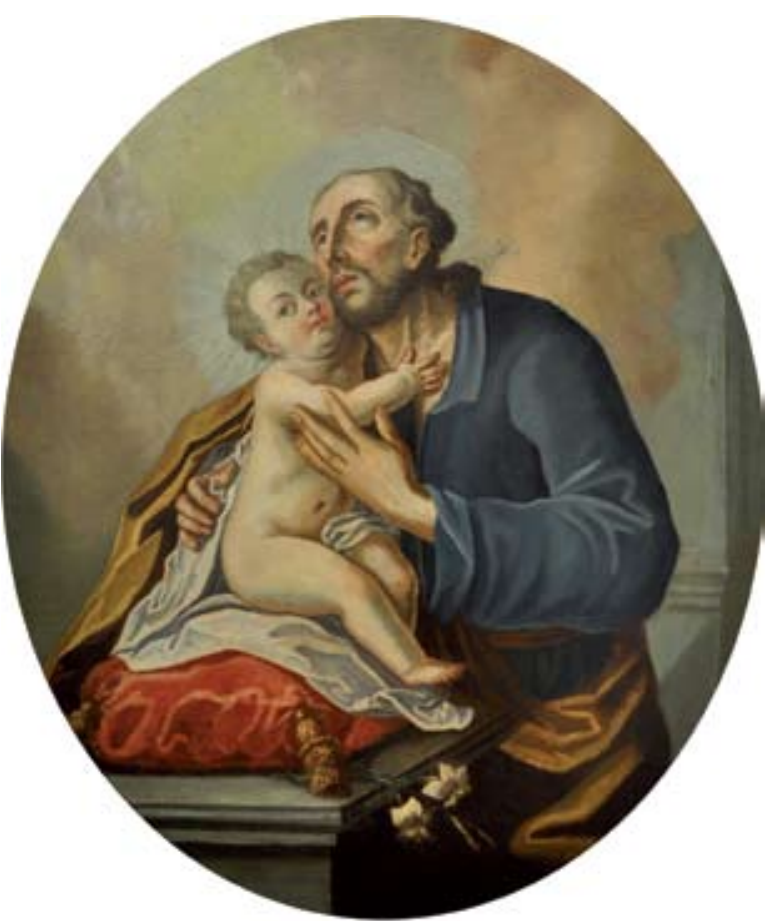

10. ábra: 18. századi szentképfestő: Férfiszent a gyermek Jézussal, Wosinsky Mór Megyei Múzeum, Szekszárd 
Nepomuki Szt. János, 18. sz. festett fa, m: 29 cm, sz: $12 \mathrm{~cm}, 7242 / 212$. Rippl-Rónai Múzeum, Rippl-Rónai Ödön gyüjteménye

Körmeneti zászló, Magyar, 1860 körül, keresztöltéses hímzés, kongré, $95 \times 50 \mathrm{~cm}$, Itsz:: 89.329. Származás: Osztopán (Somogy megye), Boldog Gizella Főegyházmegyei Gyűjtemény,

Ón keresztelö kupa, 1812. m: $39 \mathrm{~cm}$, O: 16 cm, Itsz:: 81.32.1. Rippl-Rónai Múzeum

Misecsengő a négy evengelista jelképével, 19. sz. réz, 7231/201. Rippl-Rónai Múzeum, Rippl-Rónai Ödön gyüjteménye

Áldozó kehely IHS metszéssel, 18. Sz. üveg, nyelében bordó színezéssel, m: $24,5 \mathrm{~cm}$, O: $12,5 \mathrm{~cm}$. RipplRónai Múzeum, Rippl-Rónai Ödön gyűjteménye

Luther Biblia, Nürnberg, 1589. csukva $36 \times 23.5 \times 9 \mathrm{~cm}$, rézveretes, domborított bőrkötés, papír. Zichy Mihály Emlékmúzeum, Zala

Asztali feszület, 19 . sz. $61 \times 21,5 \times 19 \mathrm{~cm}$, fa; $30,5 \times 18,5 \times 3,5 \mathrm{~cm}$ elefántcsont, Zichy Mihály Emlékmúzeum, Zala

Gyöngyfüzéses rózsafüzér fém kereszttel, RipplRónai Múzeum, Rippl-Rónai Ödön gyűjteménye

Kegytárgy miniatür ikonnal, 19. sz. fém aklád, olaj, fa, $5 \times 4,5 \mathrm{~cm}$, Rippl-Rónai Múzeum, Rippl-Rónai Ödön gyüjteménye

Ismeretlen 19. sz-i festő: Őrző angyal alvó kislánynyal, olaj, fémlemez, $17,2 \times 13,2 \mathrm{~cm}$, Rippl-Rónai Múzeum, Rippl-Rónai Ödön gyűjteménye

Angyalkórus (Donatello után), 1830 k. gipsz, m: 13 cm, sz: 9,5 cm, 7273/243. Rippl-Rónai Múzeum, Rippl-Rónai Ödön gyűjteménye

Szent Ignác, zárdamunka, 19. sz. keresztszemes hímzés, textil kartonlemez, $15 \times 12 \mathrm{~cm}, 383 / 992$. Rippl-Rónai Múzeum, Rippl-Rónai Ödön gyűjteménye

Háromkarú gyertyatartó, m: $43,5 \mathrm{~cm}, \mathrm{sz:} 35 \mathrm{~cm}$, Itsz.: 74.1.49. Rippl-Rónai Múzeum

Manipulus, textil, Itsz.: 72.17.2. Rippl-Rónai Múzeum, Rippl-Rónai Ödön gyűjteménye

Ismeretlen művész: Ferencesrendi szerzetes, 19. sz. cinklemez, olaj, 12×11,5 cm, Rippl-Rónai Múzeum, Rippl-Rónai Ödön gyűjteménye

Ismeretlen müvész: Krisztusfej, 19. sz. elefántcsont, akvarell, $9 \times 7 \mathrm{~cm}$, ovális, 276 . Rippl-Rónai Múzeum, Rippl-Rónai Ödön gyűjteménye

Asztali feszület, 19. sz. fa, fém, porcelán, Ltsz:: 84.4.1. Rippl-Rónai Múzeum, Rippl-Rónai Ödön gyüjteménye

Andocsi Mária kegyszobor, 19. sz. festett fa, m: 40 cm, Ltsz.: 74.1.59. Rippl-Rónai Múzeum
Andocsi Mária kegyszobor, 19. sz. festett fa, m: 26,5 $\mathrm{cm}$, sz: $8 \mathrm{~cm}, \mathrm{~m}: 5 \mathrm{~cm}$, Rippl-Rónai Múzeum

Andocsi Mária kegyszobor, 19. sz. (népi) festett fa, m: $15 \mathrm{~cm}$, sz: $4,5 \mathrm{~cm}, \mathrm{~m}: 3.15 \mathrm{~cm}$, Rippl-Rónai Múzeum

Madonna a gyermek Jézussal, 19. sz. cinklemez, olaj, 13×11,3 cm, Rippl-Rónai Múzeum, Rippl-Rónai Ödön gyüjteménye

Feszület, 19. sz. fa, $37 \times 14,5 \times 8,3$ cm, Rippl-Rónai Múzeum, Rippl-Rónai Ödön gyűjteménye

Szárnyas angyalka, 19. sz. (naiv) festett fa, m: 18 cm, sz:16 cm, mé:3 cm 916. Rippl-Rónai Múzeum, Rippl-Rónai Ödön gyűjteménye

Kétkaru gyertyatartó, 19. sz. vége, Itsz.: 89.6. RipplRónai Múzeum

Kétkaru gyertyatartó, 19. sz. vége, Itsz.: 89.7. RipplRónai Múzeum

Német mester (L.B): Szent Család, 1659. domborműves ezüst szentkép, fém (ezüst?) dombormü, $15 \times 11,5 \mathrm{~cm}$, Rippl-Rónai Múzeum, Rippl-Rónai Ödön gyüjteménye

Madonna a gyermek Jézussal, 19. sz. gipsz, 10×7 cm (ovális), Rippl-Rónai Múzeum, Rippl-Rónai Ödön gyüjteménye

Látomás, 18 . sz. fa, O: $26 \mathrm{~cm}$, mé: $2,5 \mathrm{~cm}, 276 / 7306$, Rippl-Rónai Múzeum, Rippl-Rónai Ödön gyüjteménye

Mater Dolorosa, zárdamunka, 19. sz. papír, tempera, fémszálas hímzés, $18 \times 13$ cm, 394/492. Rippl-Rónai Múzeum, Rippl-Rónai Ödön gyüjteménye

Madonna a gyermek Jézussal, 19. sz. gipsz, m: 23,5 cm, Rippl-Rónai Múzeum, Rippl-Rónai Ödön gyűjteménye

Két angyal, 19. sz. fa, $\mathrm{m}: 14 \mathrm{~cm}, \mathrm{sz}: 14 \mathrm{~cm}, \mathrm{~m}: 7 \mathrm{~cm}$, 7248/218. Rippl-Rónai Múzeum, Rippl-Rónai Ödön gyüjteménye

Zárdamunka csont feszülettel, 19. sz. fémszálas és gyöngyör hímzés, $11 \times 8$ cm, 7438/965. Rippl-Rónai Múzeum, Rippl-Rónai Ödön gyűjteménye

Zárdamunka Szent Antal képpel, 19. sz. textil és fémszálas hímzés, papír applikáció, $14 \times 10 \mathrm{~cm}$, 349/744, Rippl-Rónai Múzeum, Rippl-Rónai Ödön gyüjteménye

Ezüst serleg, 19. sz. m: 27 cm, O: 13,5 cm, 198. RipplRónai Múzeum, Rippl-Rónai Ödön gyűjteménye

Sárga bursa, ezüst kereszttel, 19. sz. textilvarrás, 22,5×23 cm, Itsz.: 72.17.4. Rippl-Rónai Múzeum, Rippl-Rónai Ödön gyüjteménye

Szt. Antal, zárdamunka, 19. sz. textilhímzés, akvarell, $22 \times 20 \mathrm{~cm}, 384 / 641$. Rippl-Rónai Múzeum, Rippl-Rónai Ödön gyűjteménye 
Árvák, zárdamunka, 19. sz. hímzett, festett textilkép, $24 \times 18 \mathrm{~cm}$, Rippl-Rónai Múzeum, Rippl-Rónai Ödön gyüjteménye

Rózsafüzér Szentföldről származó ereklyékkel, magántulajdon

Zsolnay mühely: Madonna, 19. sz. közepe, ovális keretben, M. $13 \mathrm{~cm}$, magántulajdon

Ismeretlen 19. sz-i miniátor: Imádkozó angyal, olaj, cinklemez, $8 \times 6,5 \mathrm{~cm}$, magántulajdon

Szent Biblia, 1626. Bécs. Fordította: Káldi György, Nyomtatta: Formika Máté (első magyar nyelvü katolikus biblia kiadás), magántulajdon

Szent Biblia, 1732. Nagyszombat, Fordította: Káldi György, Nyomtatta: Berger Leopold (második magyar katolikus biblia kiadás, magántulajdon

Szent Biblia, 1645. Amszterdam, Fordította: Cároli Gáspár, nyomtatta: Jánsonius János, magántulajdon

Az Ó- és Új Testamentum. 1571. Frankfurt. Nyomtatta Sigismundi Feierabend, fametszetek: Jost Ammant, magántulajdon

D. Aurelii Augistini (Szent Ágoston) Hipponensis Episcopi Tomus II. Párizs MDLXXXVI. - 1586., magántulajdon IN ACTA APOSTOLORUM PER DIUNM LUCAM - HOMILIE - CLXXV, authors: Rodolpho Gvalthero - 1569 Ticuri, magántulajdon
Conciones in evangélia, 1569. Antverpen, nyomtatva: Platinus műhelyben, magántulajdon

Enchi Ridionlo Corum Communium Aduertus LUTHERUM. Nyomtatva: 1567. Coloniae (Köln) Arnoldi Birckmanni, magántulajdon

Catechismo, 1580. Velence, Battista Somasco, magántulajdon

Regfugium Parochorum. 1688. Metszet: Lucae, magántulajdon

Biblia, 1812. Frankfurt és Lipcse. magántulajdon

Cserey Farkas: Isten annyának, a boldogságos szeplőtelen szép Szűz Máriának Lórétomi Litániában lévő nevezetek rendin folyó dícsérete. Bécs, 1772. Rippl-Rónai Múzeum

Orgonahangok: énekeskönyv 910 énekkel a római kath. hívek használatára. Budapest, New-York, 1929. Rippl-Rónai Múzeum

Der ander Thail: Deß Christ lichen Helden buechs, Rippl-Rónai Múzeum, Rippl-Rónai Ödön gyüjteménye

Adventi himnuszok, dícséretek, ... Rippl-Rónai Múzeum, Berzsenyi Dániel gyüjteményéből

Concordatiae Bibliorum Sacrorum: Emendatae. Venetiis, 1719. Rippl-Rónai Múzeum

Missale Parisiense, Parisiis, 1738. Rippl-Rónai Múzeum, Kaposvár

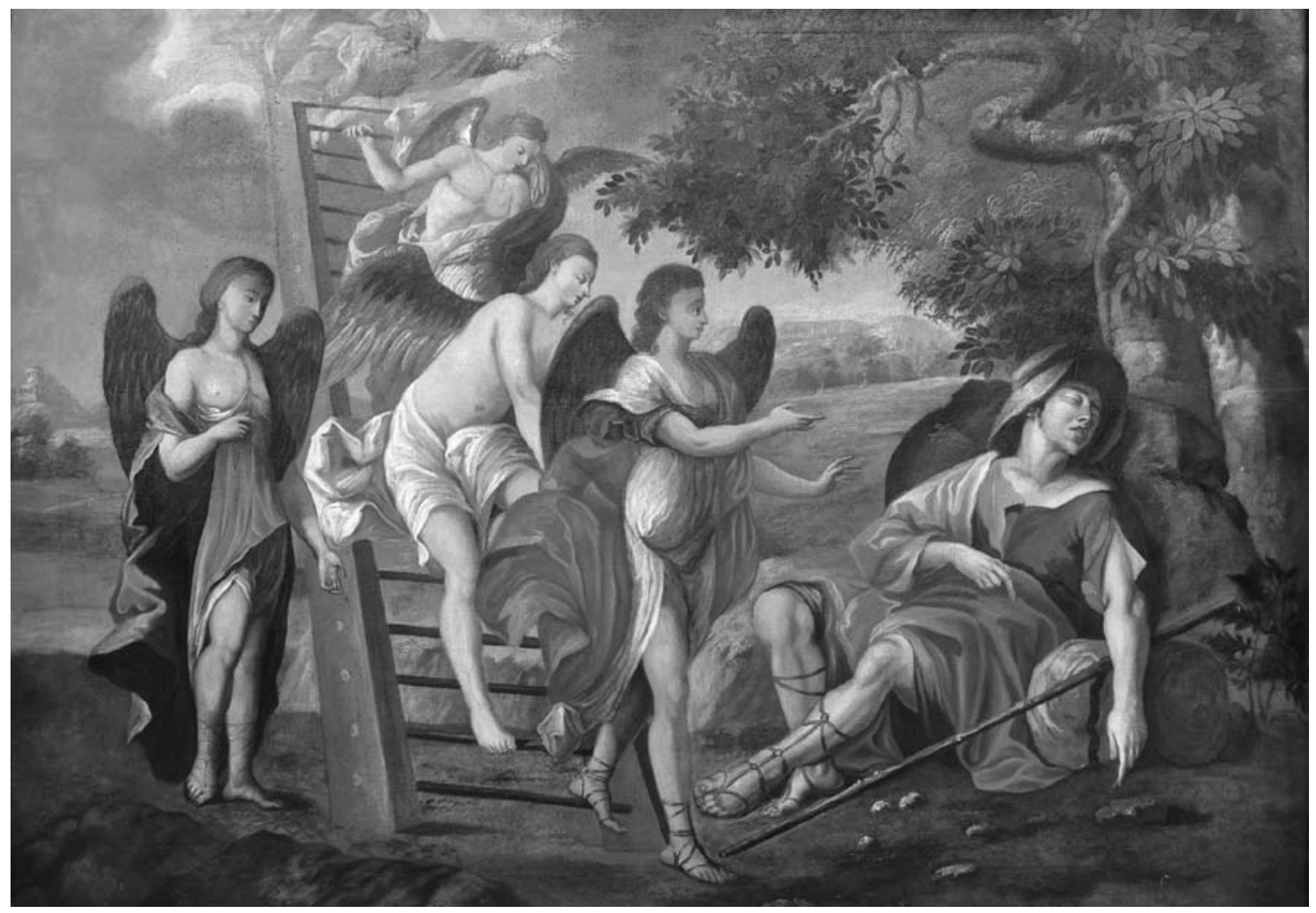

11. ábra: Ismeretlen festő: Jákob létrája, 18. század vége, Wosinsky Mór Megyei Múzeum, Szekszárd 